\title{
MOBILITY SKILLS CONDITION IN MACEDONIA AMONG YOUTH IN HIGH SCHOOL
}

\author{
Academic-DHK-Angel Dzhambazovski Center for scoliosis - Department of Anthropological kinesiology, Skopje, \\ Macedonia \\ Associent Prof. Mitrichka Ks. Stardelova - PhD in Medicine, Faculty of Physical Culture, Department of Kinesiology \\ Anthropology, Skopje, Macedonia \\ D-r.med. Nevenka Panovska Center for scoliosis and physiotherapy in Skopje, Macedonia
}

M PhD. Selim Alili freelancer cooperator, scoliosis and physiotherapy center, Skopje, Macedonia

MA. Kjamilj Elmazi freelancer cooperator, scoliosis and physiotherapy center, Skopje, Macedonia

\begin{abstract}
Within this research, the manifestation of the ontogenetic differences degree in some motor manifestations between male and female pupils is investigated, which attend a regular course in physical (Kinesiology) and health education in the secondary education in the Republic of Macedonia related to age. The total male pupils are 320 students, and 280 of female students in 8 colleges from urban and rural areas in the whole territory of our country. These samples are divided into four sub samples of the respondents for each sex separately, which are males: from I-st grade $(\mathrm{N}=75)$, II-nd grade $(\mathrm{N}=85)$, III-rd grade $(\mathrm{N}=75)$ and $I V$-th grade $(\mathrm{N}=65)$. For the assessment of the status of the respondents the mobility applied battery of tests based upon EUROFIT children program. From the obtained results the significant differences can be stated from the ontogenesis development between male and female pupils from different chronological age, suggesting a demand for differentiated programs for mobility development and kinesiology and health education.

Keyword - teaching, education, female students, male students, physical kinesiological education, morphological, mobility, differences, ontogenesis EUROFIT.
\end{abstract}

\section{INTRODUCTION}

Due to physical and health education course, the evaluation, regarding and defining of the ontogenetic development level of the motor skills to students, presents one of the basic prerequisites for the implementation of appropriate education contents. Depending on the level of the pupil's development mobility it is required to anticipate and implement the teaching adequate contents that will have the optimal effect. Namely, through the evaluation of the total condition related to the mobility student status, as well as the functional ability, followed and analyzed by the intellectual and personality characteristics, it is necessary to make an inspection of the possibilities and pupils capacities based on the objective indicators, which are manifested, to be transferred towards differentiated approach in the implementation of the realization of the education itself. An initial step in the analysis of the level of development of the mobility, is enlighten of the certain represents of the balance of the relationship by recording the differences in the ratio by the age of the students. In our present research the degree is defined through the manifestation of differences in some mobility indicators between female and male pupils who attend a regular course in physical and health education in secondary education in the Republic of Macedonia. In other researches we will perform complete analysis of the mobility, functional, intellectual and corrective personality characteristics, to examine the correlation between them.

\section{THE OPERATION METHOD}

The total sample consists of 320 male students, and 280 of female students from 8 colleges from urban and rural areas in the 
whole territory of our country. These samples are divided into the four sub samples-the respondents for each sex separately. For the evaluation of the mobility status of the respondents, the battery of tests based on EUROFIT children program was applied. For the evaluation of the mobility skills, the balancing tests on the bench, the tapping with hand, deep reach on bench, the jump in length, dynamo measurement by hand, lifting of the body within 30sec. the knuckle endurance, running 20 meters and $* 5$ meters and more gradually progressive run $-20 \mathrm{~m}$, as well as running 20 meters of sprint.

For the determination of the differences in the degree of manifestations in the overall analyzed area the multivariate analysis of variance (MANOVA) are applied, while the single differences in each variable are determined by analysis of variance univariance (ANOVA). In order to define the differences Univariate between pairs of groups of respondents in every age and every single analyzed events, is applied to the testing of these differences by appliance of the LSD (Last differences significant) test, with which actually the level of significance of the differences between each with each group in every single variable is defined.

\section{RESULTS AND DISCUSSION}

Based upon the applied multivariate analysis variance, which is determined by the differences in the overall analyzes between the mobility area surveyed by male and female respondents, the significant difference between the groups can be concluded in the level of significance of 0003 and 0005 related to their age. Univariate differences between the groups are significant in each variable mobility single analyzed in the both samples, were registered in all analyzed variables, except the variables in the balance of the bench (MRAM), tapping with hand (MTAP) and the hand shake (MSTIS).

On the basis of the defined univariate differences, it was concluded that with the pupils of both sex the proportion is evident into the increase in the overall mobility (compared to the observed area) with the chronological age of the students.

\begin{tabular}{llll}
\hline & Evaluation & $\begin{array}{l}\text { The Level of } \\
\text { Importance }\end{array}$ \\
\hline $\begin{array}{l}\text { Vilkov } \\
\text { lambda }\end{array}$ & .751624 & \\
\hline $\begin{array}{l}\text { Pao } \\
(33,595)\end{array}$ & P & 1.837385 & .003 \\
\hline
\end{tabular}

Table 1. Multivariance analyzes of variance of the male sub samples. 


\begin{tabular}{lcccccccccc}
\hline kals & mram & mtap & mdlp & mskok & mstis & mstom & mzgib & m10*5 & mleg & m20m \\
\hline 1 & 10.15 & 10.96 & 50.79 & 182.68 & 25.50 & 19.21 & 11.91 & 22.57 & 36.40 & 4.08 \\
\hline 2 & 10.66 & 11.26 & 47.18 & 186.15 & 27.71 & 19.29 & 15.70 & 21.86 & 38.01 & 3.88 \\
\hline 3 & 9.97 & 10.94 & 48.35 & 193.71 & 27.62 & 20.32 & 17.50 & 21.43 & 37.89 & 3.87 \\
\hline 4 & 10.77 & 10.43 & 44.34 & 205.52 & 27.63 & 22.74 & 22.20 & 20.04 & 43.45 & 3.70 \\
\hline
\end{tabular}

Table 2. Middle evaluation of the mobility variable of the male sub samples

\begin{tabular}{lccc}
\hline Mobility variable & Effect & $\Phi(\mathrm{df1}, 2)$ & The Level of Importance \\
\hline MRAM & 7. & .093 & .964 \\
\hline MTAP & 4. & 1.123 & .341 \\
\hline MDLP & 288. & 4.540 & .004 \\
\hline MSKOK & 3616. & 2.997 & .032 \\
\hline MSTIS & 73. & .680 & .565 \\
\hline MSTOM & 84. & 4.637 & .003 \\
\hline MZGIB & 716. & 3.576 & .015 \\
\hline M10*5 & 40. & 5.019 & .002 \\
\hline MLEG & 286. & 5.149 & .002 \\
\hline MTR20M & 1. & 4.790 & .003 \\
\hline
\end{tabular}

Table3. Univariant of analyze of variance of the female sub samples.

\begin{tabular}{lcc}
\hline & Evaluation & The Level of Importance \\
\hline Vilkov lambda & .63 & \\
\hline Pao P (31.43) & 1.83 & .005
\end{tabular}

Table 4. Multivariance analyzes of variance of the female sub samples.

\begin{tabular}{|c|c|c|c|c|c|c|c|c|c|c|}
\hline las & mram & mtap & mdlp & mskok & mstis & mstom & mzgib & $\begin{array}{c}\mathrm{m} 10^{*} \\
5\end{array}$ & mleg & $\begin{array}{c}\mathrm{m} 20 \\
\mathrm{~m}\end{array}$ \\
\hline & 10.11 & 11.46 & 51.19 & 152.16 & 23.20 & 15.54 & 8.87 & 24.57 & 35.43 & 4.88 \\
\hline & 10.21 & 11.24 & 48.14 & 166.17 & 23.51 & 16.43 & 9.54 & 23.86 & 36.64 & 4.34 \\
\hline & 10.01 & 11.13 & 49.32 & 173.11 & 23.32 & 18.31 & 9.94 & 22.43 & 37.62 & 4.20 \\
\hline & 10.32 & 11.17 & 47.24 & 184.62 & 23.81 & 20.64 & 10.25 & 23.04 & 39.53 & 3.89 \\
\hline
\end{tabular}

Table 5. Middle evaluation of the mobility variable of the female sub samples 


\begin{tabular}{lccc}
\hline $\begin{array}{l}\text { Mobility } \\
\text { variable }\end{array}$ & Effect & F(df1,2) & Importance Level \\
\hline MRAM & 6. & .086 & .876 \\
\hline MTAP & 7. & 1.102 & .315 \\
\hline MDLP & 300. & 4.431 & .001 \\
\hline MSKOK & 3537. & 2.675 & .035 \\
\hline MSTIS & 71. & .578 & .565 \\
\hline MSTOM & 79. & 4.547 & .002 \\
\hline MZGIB & 721. & 3.486 & .019 \\
\hline M10*5 & 37. & 5.631 & .001 \\
\hline MLEG & 275. & 5.026 & .004 \\
\hline MTR20M & 1.01 & 4.672 & \\
\hline
\end{tabular}

Table 6. Univariable analyses of the variance of the male sub samples

\section{CONCLUSION}

From the results of applied analysis that defined the differences in each individual morphological and mobility manifestation among male and female respondents, in terms of chronological age, it reveals significant differences between the pupils and students of different chronological age. Defined individual events of separately age, should be taken as the total content of the subject area (physical) kineziological health education in the secondary education. Besides the complete research of ontogenetic development among students in terms of mobility-functional capabilities, the antropometric, intellectual abilities and features are demanded.

For the purpose of the sport it is necessary selection to be done in all above mentioned capabilities without training as early as preschool and early school age would be developed and genetic kinesiology and children's manifest capabilities that sport is destined and what level will can be trainned.

Finally we can conclude that the need for a hour kinezioloshko (physical) health education is needed in the prevention against disease hipokinesis of the civilizational achievements.

\section{Reference}

1. Enoka. R. M.: "Osnovni kineziologii", Kiev, 2000 (Osnovi na kineziolo\{kata teorijahumana kinetika).

2. Winter DA.: Foot trajectory in human gait. Physical Therapy, Vol 72, 1, 1992

3. Блахуш П.: К теории тестированиа двигателних способностеи. Физкултура и спорт, Москва, 1982

4. Блашковиќ, М.: Релације морфолошких карактеристика и моторичких способности. Кинезиологија, 1979.

5. Бошковиќ М.: Анатомија човека. Медицинска кнјига, Београд-Загреб, 1975. 
6. Верхошански J.: Развој снаге у спорту (превод са руског), НИПРО Партизан, Београд, 1979.

7. Виски Н.: Факторска структура тјелесне тежине. Кинезиологија, 2, 1972.

8. Гајиќ М.: Основи моторике човека. Факултет физичќке културе Универзитета у Новом Саду, ООУР Институт физичке културе, Нови Сад, 1985.

9. Джамбазовски А.; Кинезиолошка медицина - спортска физиотерапија медицинска кинезиологија, Скопје 2011.

10. Старделова Дж. М.: Теорија на антрополошката кинезиологија, Скопје, 2011.

11. Старделова Џ. М.: Онтогенетскиот развој кај учениците од двата пола од основното и средното образование во Македонија како предикција за селекција во спортот, Мај 2006, Скопје.

12. Топузов И., Е. Кавдански, Д. Вчков, Н. Петрова, Г. Начева, Д. Денчева: Югозападен Университет - Благоевград, Катедра кинезитерапия „Антропометрична и функционална характеристика на ученици и студенти“"Физическото възпитание и спортът между два века, Велико Търново, 2000.

13. Топузов И., К. Бојчев, М Глушкова.: Валеологията в обучението на студентите по физическо възпитание, „Физическото възпитание и спортът между два века““ Велико Търново, 2000. 